\title{
Comprehensive Benefit Evaluation Model and Analysis Considering Multi - Energy Supply
}

\author{
Guorong Zhu ${ }^{1, a}$, Keke Wang ${ }^{2, b}$, Yi Liang ${ }^{2, c^{*}}$ and Dongxiao Niu ${ }^{2, d}$ \\ ${ }^{1}$ Economic and Technological Research Institute, State Grid Zhejiang Electric Power Company \\ LTD., Hangzhou 310008, China \\ ${ }^{2}$ School of Economics and Management, North China Electric Power University, Beijing 102206, \\ China \\ azhu_guorong@zj.sgcc.com.cn, ㅎk915783810@163.com, ${ }^{c *}$ lianglouis@126.com,
}

Keywords: Energy supply; Comprehensive evaluation; Analytic hierarchy process (AHP)

\begin{abstract}
In the context of low-carbon economy, using environment-friendly and energy-friendly energies is an important measure to achieve sustainable development. In view of the various forms of energy supply, in addition to the most basic economic factors, the paper introduces environmental and social impact, and together constitute the comprehensive benefit evaluation indicator system of energy supply mode. Taking Zhejiang province as an example, the analytic hierarchy process (AHP) is used to evaluate the energy supply in Zhejiang province and analyze the weak link of energy supply in accordance with the evaluation results.
\end{abstract}

\section{Introduction}

Electricity as a secondary energy comes from the conversion of primary energy. Thermal power is the most important power generation method in China [1], which has a great cost competitiveness, but it is also often criticized for its pollution. Since China's energy consumption has long been dominated by coal, its $\mathrm{CO}_{2}$ emission accounts for about $80 \%$ of the total domestic emissions of various greenhouse gases [2]. A large amount of coal has become the main cause of air pollution and acid deposition [3].

To achieve the emission reduction target of 2020 [4], in addition to vigorously adopting various energy-saving measures, also need to take actions to reduce emissions. Adjust the energy structure and develop non-fossil energy sources, especially to develop nuclear power and renewable energy power generation [5]. To comprehensively weigh multiple energy supply modes, environmental impacts and social impacts are also important considerations [6,7], and the the economic, environmental and social aspects of each energy supply mode need to understand for assessing the impact of different energy supply modes overall benefit.

This paper sets up a comprehensive evaluation indicator system of energy supply mode, make a comprehensive evaluation of different energy supply modes, compare the advantages and disadvantages of different energy supply modes through horizontal and vertical comparison of indicator scores, and weigh the economic benefits, environmental benefits and Social benefits.

\section{Comprehensive Evaluation Indicator System of Energy Supply Mode}

This paper constructs the indicator system of comprehensive benefit evaluation of energy supply from three aspects of economy, environment and society. Economic indicators reflect the cost of energy supply; with the goal of building a resource-saving society put forward, environmental costs have become an important cost of generating enterprises, environmental impact cannot be ignored [8]; different modes of energy supply will cause to society and residents of the impact of the proposed social indicators, and quantify the indicators, as assessable indicators. 
Table 1 Comprehensive Evaluation Indicator System of Energy Supply Mode

\begin{tabular}{ccc}
\hline Target Layer & Criterion Layer & Indicator Layer \\
\hline & Economic & Energy Supply Costs $\left(C_{11}\right)$ \\
& Investment $\left(C_{1}\right)$ & Reliability of Energy Supply $\left(C_{12}\right)$ \\
& & Resource Consumption $\left(C_{13}\right)$ \\
\cline { 2 - 3 } $\begin{array}{c}\text { Comprehensive } \\
\text { Benefits of } \\
\text { Energy Supply } \\
\text { Mode }\end{array}$ & Environmental & Carbon Emission $\left(C_{21}\right)$ \\
& Protection $\left(C_{2}\right)$ & Emission of Air Pollutants (Particulate Matter of Gas and \\
& Social & Dust $)\left(C_{22}\right)$ \\
& Influence $\left(C_{3}\right)$ & Pollution Levels of Soil and Water Resources $\left(C_{23}\right)$ \\
& & GDP Driven Performance $\left(C_{31}\right)$ \\
& & Impact on The Surrounding Residents $\left(C_{32}\right)$ \\
& & Impact on The Ecological Environment $\left(C_{33}\right)$
\end{tabular}

\section{Comprehensive Benefit Evaluation of Energy Supply Modes Based on AHP}

AHP. AHP is a multi-objective decision analysis method combining qualitative analysis with quantitative analysis [9]. It decomposes complex system as a whole and makes multi-objective and multi-criteria decision-making into multi-level and one-goal pairwise comparison, and then carries on the simple mathematical operation.

Using AHP modeling to solve problems can be divided into four steps:

Step 1: establish a hierarchical model of substructure.

Step 2: construct all the judgment matrix in each level.

A comparison of the significance of the two factors is made by using the numbers 1 to 9 and their reciprocals as the scale to judge the matrix $A=\left(a_{i j}\right)_{n \times n}, a_{i j}$ means that for a certain factor in the upper level, the $i$ th factor Relative to the $j$ th factor of importance, as shown in Table 2.

Table 2 The significance of indicators

\begin{tabular}{|c|c|c|}
\hline Significance & Meaning & Explanation \\
\hline 1 & The two factors are equal in important & $\begin{array}{l}\text { The two factors contribute equally to the } \\
\text { goal }\end{array}$ \\
\hline 3 & One factor is more important than another & $\begin{array}{l}\text { There is a slight difference between the } \\
\text { two }\end{array}$ \\
\hline 5 & $\begin{array}{l}\text { One factor is obviously more important } \\
\text { than another }\end{array}$ & The difference between the two is obvious \\
\hline 7 & $\begin{array}{c}\text { One factor is more important than another } \\
\text { strongly }\end{array}$ & $\begin{array}{l}\text { There is a strong difference between the } \\
\text { two }\end{array}$ \\
\hline 9 & $\begin{array}{l}\text { One factor is definitely more important } \\
\text { than the other }\end{array}$ & $\begin{array}{l}\text { The difference between the two is } \\
\text { extreme }\end{array}$ \\
\hline $2,4,6,8$ & $\begin{array}{l}\text { The intermediate values of the above two } \\
\text { judgments }\end{array}$ & Coordinated judgment value \\
\hline
\end{tabular}

Step 3: Hierarchical order and consistency test.

(1) Calculate the consistency indicator.

Then the hierarchical order is sorted to obtain the eigenvectors of the judgment matrix. By $A W=\lambda W$, the largest eigenvalue $\lambda_{\max }$ of the matrix $A$ can be obtained. 
(1)

$$
C I=\frac{\lambda_{\max }-n}{n-1}
$$

(2) Find consistency indicator $R I$.

Look up the table to get the average random consistency indicator $R I$, then calculate the random consistency ratio $C R$.

Table 3 Average random consistent indicator

\begin{tabular}{lrrrrrrrrrrrrr}
\hline$n$ & 3 & 4 & 5 & 6 & 7 & 8 & 9 & 1 & 1 & 1 & 1 & 14 \\
& & & & & & & & 0 & 1 & 2 & 3 & \\
\hline$R I$ & 0. & 0. & 1. & 1. & 1. & 1. & 1. & 1. & 1. & 1. & 1. & 1.58 \\
& 52 & 89 & 12 & 24 & 36 & 41 & 46 & 49 & 52 & 54 & 56 & \\
\hline
\end{tabular}

(3) Calculate the proportion of consistency.

$$
A=C R=\frac{C I}{R I}
$$

When $C R<0.10$, that the consistency of the judgment matrix is acceptable, otherwise the judgment matrix should be properly amended.

Step 4: Overall ranking and consistency test.

The overall ranking also need to make a consistency test, calculate the composition of the various elements of the total weight of the system of synthetic goals, and the various options sorted. According to this procedure, comprehensive evaluation of energy supply methods and comparative analysis of advantages and disadvantages of different energy supply methods.

Determine the Weight of the Indicators. The weight of indicators is determined by expert scoring method [10]. Taking Zhejiang Province of China as an example, 20 experts in Zhejiang-related energy-related fields are invited to score each index according to the scale of 1 to 9 , and the weight calculation results of each index are obtained, as shown in Table 4.

Table 4 Weight calculation result

\begin{tabular}{ccccc}
\hline \multirow{2}{*}{ Target Layer } & Criterion Layer & $\begin{array}{c}\text { Weighs of } \\
\text { Criterion } \\
\text { Layer }\end{array}$ & $\begin{array}{c}\text { Indicator } \\
\text { Layer }\end{array}$ & $\begin{array}{c}\text { Weighs of } \\
\text { Indicator } \\
\text { Layer }\end{array}$ \\
\hline & \multirow{2}{*}{ Economic Investment $\left(C_{1}\right)$} & & $C_{11}$ & 0.62 \\
& & 0.6 & $C_{12}$ & 0.24 \\
\cline { 3 - 5 } & & & $C_{13}$ & 0.14 \\
Comprehensive & & $C_{21}$ & 0.11 \\
Benefits of & Environmental Protection $\left(C_{2}\right)$ & 0.2 & $C_{22}$ & 0.44 \\
Energy Supply & & & $C_{23}$ & 0.44 \\
\cline { 2 - 5 } Mode & & & $C_{31}$ & 0.08 \\
& Social Influence $\left(C_{3}\right)$ & 0.2 & $C_{32}$ & 0.34 \\
& & & $C_{33}$ & 0.58 \\
\hline
\end{tabular}

Based on the index weight value, the judgment matrix was constructed and the consistency test was performed. After calculation, the indicators passed the consistency test.

Comprehensive Benefit Evaluation of Energy Supply Modes. Invited Energy 20 experts in the field of energy-related indicators of scoring in Zhejiang, the questionnaire on the evaluation of energy 
supply indicators of the issue of using 10 points for scoring, for economic indicators, 10 points that the economic costs of the smallest, 8 points smaller , 6 points indicate normal, 4 points indicate poor, and 2 points indicate poor; for environmental protection indicators, 10 points indicate environment-friendly energy supply, 8 points indicate environmental protection, 6 points indicate normal, 4 points indicate more serious pollution, and 2 The points indicate the highest degree of pollution. The social impact assessment rules are similar to environmental protection, with 10 points indicating that the society is friendly and 2 points are poor.

Table 5 Experts scoring results

\begin{tabular}{cccccccc}
\hline Target Layer & $\begin{array}{c}\text { Criterion } \\
\text { Layer }\end{array}$ & $\begin{array}{c}\text { Indicator } \\
\text { Layer }\end{array}$ & $\begin{array}{c}\text { Thermal } \\
\text { power }\end{array}$ & $\begin{array}{c}\text { Nuclear } \\
\text { power }\end{array}$ & Hydropower & $\begin{array}{c}\text { Wind } \\
\text { Power }\end{array}$ & $\begin{array}{c}\text { Photovoltaic } \\
\text { Power } \\
\text { Generation }\end{array}$ \\
\hline & & $C_{11}$ & 10 & 8 & 6 & 5 & 3 \\
& $C_{1}$ & $C_{12}$ & 10 & 10 & 8 & 4 & 4 \\
\cline { 3 - 8 } & & $C_{13}$ & 6 & 4 & 10 & 10 & 9 \\
Comprehensive & & $C_{21}$ & 4 & 10 & 10 & 10 & 10 \\
Benefits of & $C_{2}$ & $C_{22}$ & 4 & 10 & 10 & 10 & 10 \\
Energy Supply & & $C_{23}$ & 6 & 6 & 10 & 10 & 10 \\
\cline { 2 - 8 } Mode & & $C_{31}$ & 10 & 6 & 6 & 6 & 6 \\
& $C_{3}$ & $C_{32}$ & 7 & 4 & 6 & 6 & 10 \\
\hline
\end{tabular}

According to the above indicators to determine the weight, calculate the price of different energy supply comprehensive evaluation results, as shown in Table 6.

Table 6 Comprehensive evaluation of energy supply modes score

\begin{tabular}{cccccc}
\hline Energy Supply Modes & $\begin{array}{c}\text { Thermal } \\
\text { power }\end{array}$ & $\begin{array}{c}\text { Nuclear } \\
\text { power }\end{array}$ & Hydropower & $\begin{array}{c}\text { Wind } \\
\text { Power }\end{array}$ & $\begin{array}{c}\text { Photovoltaic } \\
\text { Power } \\
\text { Generation }\end{array}$ \\
\hline Economic Investment & 9.44 & 7.92 & 7.04 & 5.46 & 4.08 \\
Environmental Protection & 4.84 & 8.14 & 9.9 & 9.9 & 9.9 \\
$\begin{array}{c}\text { Social Influence } \\
\text { Comprehensive evaluation } \\
\text { of energy supply modes }\end{array}$ & 6.66 & 6.48 & 6 & 8.32 & 9.68 \\
\hline
\end{tabular}

\section{Conclusions}

This paper combines the environmental impact and social impact of energy supply with the cost of energy supply, establishes a comprehensive evaluation indicators system of energy supply mode and applies AHP to evaluate it comprehensively. With the proposed goal of reducing carbon emissions and the implementation of energy conservation and emission reduction policies, the environmental costs of power generation enterprises will further increase. It is imperative to speed up the development of clean energy. Hydropower installed capacity is second only to thermal power. Wind power has great potential in our country. However, wind power resources in China are mainly distributed in the western and northern regions with low electricity load and long-distance wind power transmission. Solar energy is the most abundant renewable energy that can be fully utilized to meet all of country's energy needs. 
However, solar energy development is still in its infancy. With the development of advanced manufacturing technology, the cost of photovoltaic power generation will be further reduced. At this time, the environmental protection advantages of photovoltaic power generation will be further highlighted.

\section{Acknowledgements}

This work is supported by the technology project of Economic and Technological Research Institute, State Grid Zhejiang Electric Power Company LTD (Project name: "Research on Flexible and Intelligent Energy Supply and Consumption Ecological Community in Electricity Market").

\section{References}

[1] L.X. Dai, Z.H. Li and X.Y. Wang. Determination of Ecological Compensation Standard for Thermal Power Enterprises - Based on Environmental Accounting Perspective [J] .A Friends of Accounting, 2014 (3): 118-120. (In Chinese)

[2] N. Li, M. Wan. Research on environmental cost calculation of thermal power plants [J]. Shaanxi electric power, 2008, 36(2):16-18. (In Chinese)

[3] W. Meng. Environmental Protection and Electric Safety [J]. China Power Enterprise Management, 2003 (11): 35-37. (In Chinese)

[4] J.K. He. Peak $\mathrm{CO}_{2}$ emission analysis: China's emission reduction targets and countermeasures [J]. China Population, Resources and Environment, 2013, 23 (12): 1-9.

[5] T. Jiang, X.Y. Sun. Countermeasures to realize China's energy conservation and emission reduction targets [J]. Legal and economic, 2009(2):130-131. (In Chinese)

[6] Y.Q. Xu, Y.X. Wang and C. Li. Calculation of Environmental Costs - A Case Study of Thermal Power Plants [J] .Accounting Research, 2002,3 (3): 49-53. (In Chinese)

[7] S.Y. Wang, M.P. Chen, K. Wange, et al. Analysis of low carbon policies and socio-economic impact of China's electric power industry [J]. China's population, resources and environment, 2010, v.20;No. 117 (s2) : 14 to 18 . (In Chinese)

[8] T. Fang, L.C. Li and L.Z. Zhang. Environmental costs of power generation companies [J]. China Power, 2005, 38 (11): 16-20.

[9] Al-Harbi A S. Application of the AHP in project management[J]. International Journal of Project Management, 2001, 19(1):19-27.

[10] Y.J. Wu, Y.Q. Su and L.X. Cheng .Evaluation of Enterprise Energy Efficiency and Emission Reduction Based on Entropy Method and Expert Scoring Method [J] .Electrical \& Energy Management, 2015 (16): 63-68. ) 